\title{
Ontology in Neolithic Britain and Ireland: Beyond Animism
}

\author{
Chris Fowler
}

check for updates

Citation: Fowler, Chris. 2021. Ontology in Neolithic Britain and Ireland: Beyond Animism. Religions 12: 249. https://doi.org/10.3390/ rel12040249

Academic Editors: Robert J. Wallis and Max Carocci

Received: 22 February 2021

Accepted: 25 March 2021

Published: 1 April 2021

Publisher's Note: MDPI stays neutral with regard to jurisdictional claims in published maps and institutional affiliations.

Copyright: (c) 2021 by the author. Licensee MDPI, Basel, Switzerland. This article is an open access article distributed under the terms and conditions of the Creative Commons Attribution (CC BY) license (https:/ / creativecommons.org/licenses/by/ $4.0 /)$.
School of History, Classics \& Archaeology, Newcastle University, Newcastle Upon Tyne NE1 7RU, UK; chris.fowler@ncl.ac.uk

\begin{abstract}
A combination of new animism and new materialism has influenced recent interpretations of the Neolithic archaeology of Britain and Ireland, including decorative and figurative productions often referred to as 'art'. This article queries the appeal to animism in some of this work and considers four alternative ways to react to the use of the term. First it considers contextualizing animism by discussing Descola's identification of four kinds of ontologies-animism, totemism, analogism and naturalism-outlining examples of practices and material culture involved in each. After examining the effect of applying these to the Neolithic archaeology of Britain and Ireland, it then considers identifying Neolithic practices which seem at odds with animism without boxing these as indicative of other categories of ontology. After noting the wide range of Indigenous ontologies such models attempt to characterize, the article advocates an emphasis on ontological difference and attends to ontological diversity within the Neolithic.
\end{abstract}

Keywords: animism; totemism; analogism; art and architecture; mortuary practices; Neolithic Britain and Ireland; ethnographic analogy

\section{Introduction}

A combination of 'new materialism' and 'new animism' has led to some inspiring and influential interpretations of British prehistory over the last twenty years. In some cases the implications of these approaches have been explored without identifying a specific form of prehistoric ontology (e.g., Conneller 2004) ${ }^{1}$; in other cases a generalied sense of an animate world or animism is referred to (e.g., Johnston 2020, p. 20; Jones 2006; Jones et al. 2011; Pollard 2013; Richards 2013, pp. 27-29; Wallis 2009); and in rare cases specific versions of animism have been proposed (e.g., Wallis 2014). I am challenged by the theme of this Special Issue to consider the place of animism in understanding Neolithic Britain and Ireland (c. 4000-2500 BC), particularly in interpreting art, monumental architecture and mortuary practice. I will relate some concerns about the use of anthropological categories in this pursuit, and argue that we need to either set any interpretation of animism and animacy in the Neolithic in a broader ontological context or-far better-move beyond such categorization in favour of an appreciation of ontological difference which also attends to ontological diversity within the period.

\section{From Cosmology to Ontology in Studying Neolithic Britain and Ireland}

An interest in the new animism developing in anthropology-attending to the relationality of living worlds and the embeddedness of humans with other-than-human

1 Conneller's analysis does not draw an analogy with Viveiros de Castro's ethnographic context but rather combines her reading of his analytical appreciation of that context with her own reading of Deleuze and Guatarri. Her account emphasises the specific archaeological evidence from Star Carr and does not compare that with material culture from an Amazonian community—rather, she draws on the philosophical basis of Viveiros de Castro's (1998) description of perspectivism, which is animist in character, to inform her own work. Yet there is an implication that the animal body parts at Star Carr were active in a perspectivist form of efficacy: '[t]he connection of the antler effects to the human body, which necessitated the taking on of the animal's bodily perspective, produced a new kind of body and way of acting in the world.' (Conneller 2004, 53 my emphasis). Conneller warns against using analogy to infer social organization or identity, and does not conclude that Mesolithic communities at Star Carr were animistic, but perspectivism is discussed in her article whereas totemic practices and understandings are not. This raises the question of which cultural contexts provide our theoretical inspirations, and what effect that has on the final interpretation. 
beings in those worlds (e.g., Bird-David 1999)—followed a period in which shamanism and cosmology had been posited as core to interpreting Neolithic art ${ }^{2}$ and monuments. The Neolithic megalithic art of Ireland (i.e., carved, pecked and incised motifs at passage tombs) was interpreted via Lewis-Williams and Dowson's neuropsychological model which identified altered states of consciousness as a means by which certain abstract motifs could be generated by the human nervous system (e.g., Bradley 1989; Lewis-Williams and Dowson 1993; Dronfield 1995; Lewis-Williams and Pearce 2005). These interpretations argued that that some common motifs in Neolithic passage tomb art were diagnostic of entoptic phenomena that would be seen during altered states of consciousness. Some accounts associated these with the presence of Neolithic ritual specialists undergoing trance experiences to transcend the layers of a vertically ordered tripartite cosmos (e.g., Lewis-Williams and Pearce 2005). Interpretations of trance and shamanism had limited impact in Neolithic studies, however, since there are questions about the ethnographic basis of the model (Solomon 2014), geometric motifs such as lattices, lozenges, chevrons and spirals need not derive from entoptic phenomena, altered states of consciousness need not involve shamans entering trances, identifying the broad category of 'shamanism' does not help much with understanding this period (Jones 2017), and shamanism is seldom identified in sedentary agricultural communities of the kind that was inferred at the time for later Neolithic Ireland.

Other studies of cosmology in the British Neolithic have been more influential, such as Colin Richards' analyses of Late Neolithic houses, passage tombs and the Stone of Stenness henge on Orkney (Richards 1990, 1993, 1996a). These studies combined contextual post-structuralist and experiential approaches, the former being largely influenced by studies such as Henrietta Moore's ethnography of Marakwet communities in East Africa which exhibit a highly structured organization of space, substance and gendered activities (Moore 1986) and Bourdieu's studies of Berber communities which exhibit similar degrees of structuring (Bourdieu 1970; cf. Richards 1996b). Richards and others argued that routines of practice guided by forms of architecture could inform us about the organization of time, space and experience-the organization of the cosmos and society.

Studies from the 1990s and early 2000s were not so much directed towards studying ontology as religious or spiritual practice and cosmology. Since the mid-2000s the emphasis has shifted away from detecting such highly structured spatial patterns in several related directions which share an emphasis on relationality and draw on what have become known as new materialist approaches. One is a focus on the process of building monuments, especially the way that monuments emerged from events in which people worked with materials and places that had distinctive properties to produce specific ontological effects (e.g., Gillings and Pollard 2016; Harris and Crellin 2018; Jones 2020). For instance, Lesley McFadyen's work on 'quick architecture' (McFadyen 2006) situates people's bodies in the messy process of rapidly constructing an early Neolithic chambered long cairn, while Colin Richards' recent work on stone circles stresses diversity in the way such monuments were built and in the effects their construction achieved (e.g., Richards 2013; Richards and Wright 2013). Some studies of Late Neolithic passage tomb art have focused on the process of its creation and the experiential effects this produced rather than its symbolic meaning (e.g., Jones 2004; Jones 2012; Cochrane and Jones 2012; Jones and Diaz-Guardamino 2019). We will return to process-oriented approaches concerned with ontologically distinctive affect towards the end of the article.

Some interpretations also describe a generalised animistic ontology. Joshua Pollard's reflection on the charged animacy of chalk banks and ditches at Late Neolithic Avebury is a good example. Pollard $(2012,2013)$ argues that the Wessex chalkland landscape and its materials resonated with special meanings and effects, suggesting

2 There is no room to discuss the use of the term art and its definition (for an excellent recent discussion see Robb 2017). The making of Neolithic motifs, images, sculptures was to my mind a form of effective and potent action equivalent to, for instance, the decorating of pottery or the polishing of axeheads. 'Art' production has profound and varied ontological effects (cf. Jones 2017). 
'...recognition of an ontological status different to that of modern geological definitions; perhaps even, on occasions, stones being perceived as invested with a certain animism...' (Pollard 2012, p. 98)

Pollard (2013) also draws a direct analogy with Polynesian concepts of mana and tapu, accentuating the volatility and danger of potency without presuming effective control of this potency through hierarchical political power (which has often been previously inferred as lying behind the construction of large henge monuments such as Avebury). Pollard explains that an animistic ontology could sit with a variety of forms of social organization.

Pollard's interpretations are subtle, insightful and productive, and exemplify much of what is presented below as the way forward. At the same time mentions of animism in prehistory, even in passing, make me wonder whether we ought to give some shape and boundary to the concept, and set it alongside other ontological possibilities for the period. I can think of four ways to approach this. Firstly, we can define what we mean by animacy and animism by comparison with other ontological frameworks. Comparison with ontologies categorized as totemism and analogism by Phillipe Descola (2013, 2014a, 2014b) would be one possible way to contextualize animism under this perspective. Secondly, we could highlight aspects of Neolithic activity that do not seem to be animistic, without yoking those to some other ontological category, in order to distinguish different ontological modes. Thirdly, we could take from new animism (and new materialism) a critique of the ontological basis of archaeology (and other disciplines with western and colonial origins) and use that to deconstruct our preconceptions about ontology (Alberti 2016; Todd 2016). This leaves the door open for things and places to be animate or socially and spiritually affective entities without evoking animism as an ontology. Fourthly, and also in keeping with the third move, we could reject the usefulness of ontological categories such as animism for appreciating ontological difference. Instead of seeking categorical terms for past ontologies we can instead focus on the relational affects of prehistoric bodies and other media, for instance (e.g., McFadyen 2006; Harris and Crellin 2018). I will explore the first and fourth approaches in most detail, and, given the focus of this Special Issue, I will discuss the role of 'art' wherever possible.

\section{First Approach: Comparing Categories of Ontologies by Deploying a Model}

In order to do justice to the first approach I have considered the material aspects of animistic, totemic and related ontologies as cast by Philippe Descola in order to think about what these materialities do and how they might be used as heuristics in refining our interpretation of prehistoric ontologies. Descola has formulated a comparative perspective on ontologies over the last two decades and crystalized these into a heuristic schema (most comprehensively set out in English in Descola 2013). He defines ontology as 'basic assumptions as to what the world contains and how the elements of this furniture are connected' (Descola 2014a, p. 273), and 'framing devices' that shape 'interactivity' (ibid., p. 274). He argues that cosmologies and what he calls 'social collectives' distribute the components of ontologies in a patterned way in time and space (Descola 2014a, p. 278; Descola 2014b, p. 437). In his view ontologies are part of the fundamental conditions for what is possible-they are how the character of the world, entities and relations (including forms of power) are perceived. Descola identifies four ontological categories: naturalism, animism, analogism and totemism. Descola uses the term naturalism to refer to western ontologies that emerged from the Enlightenment period and dominated the nineteenth and twentieth centuries AD in particular. In this ontology nature is classified endlessly and divided by species, forms and materials. The human species is treated as exceptional: we visit a zoo, but our role there is unique compared with the other animals. The social world is organized by and revolves around humans. Within our own species differences exist by culture or society. Personhood is largely individual, indivisible and the province of human beings alone (but see Fowler 2004, pp. 16-22; 2016, pp. 404-5).

In animistic ontologies, Descola argues, 'nature' is modelled on 'society', so there is one society of beings with many natures-human, jaguar, tapir, etc. Relationships 
take place between equals, specific individuals who may be human or jaguar or tapir. Non-human beings are negotiated with dialogically: some of those beings may reveal themselves to be persons. Shamans intercede in the dialogue if needed-essentially to put right any grievances and heal any injuries arising from difficult interactions. Such interactions are not all equal nor necessarily peaceful, and Descola emphasises predation and giving as two different modes of relations common in animistic communities. Descola (2013, p. 332) argues that animists do not venerate their dead ancestors, but the dead may be animate and have to be treated and transformed with care. The transmission of skills and knowledge is more important than genealogical transmission or the tracing of lineages. Social action continually activates and renews the world, and therefore Descola classifies animism as anthropogenic. If totemism and analogism are seen as forms of animism (as Sahlins 2014, suggests), Descola's animism is arguably best described as perspectivism, as defined by Viveiros de Castro (1998), although the latter would dispute such categorization (Latour 2009, p. 2).

When Descola selected examples of art for each of his ontological categories for an exhibition in Paris in 2012 he chose a transformation mask from the north-west coast of North America to exemplify the duality of the interior-exterior relationship he sees as central to animism (Simay and Descola 2012). Such masks are designed to display transformation: in its closed position, for instance, Kwakwaka'wakw Eagle masks, show the head of an eagle, but if the wearer pulls strings threaded through the eagle's head, its face opens up to reveal a carved human face beneath. For Descola this reveals the fact that human and animal are equivalent (cf. Ingold 2000)—although these masks also depict the totemic animal of the eagle clan. Descola does not say much about the material foundations of animism beyond this depiction of a shared interiority. Ingold (2000) stresses the naturalism of animistic depictions of animals, shown in motion, while Bird-David (2006) has discussed the scarcity of decoration and figurative depictions in immediate return foraging communities, among whom, she says, performers act differently as they engage with the beings seen in visions (Bird-David 2006, p. 39). She concludes that unlike circumpolar animists, Nayaka animists in South India do not categorize the perspective of non-human persons differently to their own: such beings 'cannot be looked at; rather one has to look with them sharing a perspective' (ibid., p. 48, original emphases). While performers shift stances in engaging with other beings, they do not change their bodily form or affordances so do not therefore adorn their bodies with animal body parts or imagery or masks. Different art, different engagement, different ontology; at the very least, this suggests different animisms.

Descola's definition of totemic ontologies draws heavily on ethnographies of Aboriginal Australian communities. Power, vitality, comes from the action of beings that created the landscape (i.e., from the past), and is invested in places as life energies which pass directly into people who are conceived at those places (i.e., it lies within the landscape and flows from there into bodies). These places frequently include bodies of water. According to Descola (2013, p. 263), human lineage may be less important than this connection with an ancestral being. Totemic communities are internally differentiated according to which ancestral being each member derives from, and communities are conglomerations of those different beings. The community is segmented, with each segment consisting of human and non-human beings which share some ancestral connection (ibid., p. 258). There may be overlapping means of segmentation, including by kinship, sex, generation, place of birth or conception and cult (ibid., p. 259). Non-human beings such as animals can be like persons, and are also derived from ancestral beings, but lack a creative element specific to human beings (ibid., p. 298): humans and non-humans are analogues for one another but not the same kinds of entities (ibid., p. 294: 'animals and plants are not persons', he argues). Totemic places are curated and creation events ritually re-enacted there; rites of renewal are crucial in practising these cosmogenic ontologies. Ritual knowledge is passed down from a senior to a junior practitioner throughout life. According to Descola, and Ingold (2000), shamanism is not a feature of totemic ontologies, and while animistic ceremonies negotiate 
with other-than-human beings, totemic ceremonies renew the world by re-enacting creation events. Totemic communities change in ways that are situated within, and renew and reaffirm, tradition (cf. Morphy 2007, pp. 72-82).

Totemic images depict a prototype of originary power which Descola says 'unites a variety of species... descended from this model'. Art also illustrates the traces of those beings in the landscape. Howard Morphy (2007, p. 42) describes how Yolngu motifs depict designs worn on the bodies of the creation time beings - making art is a special practice which reveals 'the reality of the unseen... underlying forces in the landscape' (ibid., p. 88); motifs are scaled to fit on the human body where they were painted during mortuary rites (Morphy 2007, p. 75) and rites of passage (ibid., p. 94). Yolngu painting actively reveals ancestral presence through the 'shimmering' effects of colours, contrasts between delineated areas of light and dark, and cross-hatching (ibid., p. 92). Designs belong to clans, but variation in motifs among neighbouring clans may be extremely subtle (ibid., p. 100). The meaning of geometric motifs is polyvalent (ibid., p. 103), so the seemingly abstract motifs support curated knowledge which is needed to interpret them. Ingold (2000) stresses the depiction of humans and other beings in ways that show the combination of ancestral essences within their bodies. As with animistic ontologies, figurines of humans or animals are made in ephemeral media. Funerary structures, like log mortuary containers, were left to decay after use (Oxenham et al. 2008, p. 50); in some regions mounds were raised over burials or burial structures (Oxenham et al. 2008, pp. 43-44). The dead can mediate between spirit beings and the living, particularly during their mortuary transformation. Some funerary architecture, such as sand sculptures which temporarily house the bodies of the dead or mourners surrounding the time of the funeral, are very ephemeral while others last for a few years but are left to decay naturally. By contrast, stones or hard wood plaques or panels, tjurunga, may be curated for generations at sites associated with totemic beings. These are decorated with circular and linear motifs. In some cases, trees next to burial sites were also carved with designs-sometimes daubed red, especially during rites of world renewal (ibid., pp. 44-45).

Descola's final category is analogism. Power derives from the alignment of society with the cosmos-it is cosmocentric. Properties are carefully divided into complementary categories which are distributed among the elements, celestial bodies, colours, body matter, times of day, the year, or life-course, and the directions of the compass. The concept of humours is a good example of how the same differentiated elements are present in the body and wider world: phlegm (water), black bile (earth), yellow bile (fire), and blood (air). The same patterns are evident at different scales through a process of homology (or shared form) and shared orientation: bodies, houses, tombs and landscapes are presented as analogous in form and composition. Beings are understood as different in kind and composition. Lineages, classes or castes may be formed out of the fixed properties invested in things, materials, places, substances and bodies. Human genealogy may be a concern, including the veneration of human ancestors, and potentially traced back to divine ancestors. Sacrifice is common. There are often multiple deities each with discrete fields of responsibility. Heterarchical relations where people are divided into distinct groups which may be ranked in some but not all domains of activity are prevalent, but may give way to hierarchical relations where one form of ranking is authorative in all realms of activity. In the latter case certain groups become predominant in the community, such as deceased ancestors or a priestly class. Descola's examples include city states and indigenous communities in north America (e.g., the American Southwest), upland South America, the Tallensi of west Africa, Hawaii, and pastoralists from Siberia and West Africa. Analogism thus groups together diverse societies with different subsistence bases, population densities, social institutions, etc. Art and architecture can include cosmograms, while beings are often depicted with set attributes (e.g., carrying certain objects), and somet are as hybrids combining the physical attributes of different species.

Art is an integral part of ontology, and I have considered the art forms associated with each of Descola's categories. Animistic ontologies might have no or little figurative 
art because human actors are so embedded in relations they do not depict them from the outside, or might depict the natural poses and motions of animals (Ingold 2000), and sometimes reveal their interior personhood. Here, art is a media for dialogue between beings. Totemic ontologies illustrate the pervasiveness of relationships that conjoin different ancestral essences within bodies and/or trace ancestral events that produced that result; art is a means of affirming and renewing these ancestral connections. Analogic art demonstrates the graded order of the cosmos with power figured at a central point; art serves to represent or bring about the order. David Wengrow (2014) has argued on the basis of hybrids in art that analogism is first properly evident in European prehistory with the emergence of Bronze Age states in the near East-however, it is not clear that all analogic ontologies produce such artworks given the breadth of Descola's category ${ }^{3}$.

This approach seems appealing in offering some material anchorage for drawing inferences about ontology. However, inferring such categories of ontologies from prehistoric art or other archaeological evidence-and even in ethnographic studies-is far from straight forward. For instance, there is a blurred boundary between Descola's view of animism and totemism whereby aspects of the two are combined: Descola (2014b, pp. 485-86) outlines how the Amazonian Tukano relate the journey of ancestral anacondas, one of whom donated part of its body to form their human ancestors, and whose community maintains distinct descent segments-which sounds rather totemic. He also identifies Exirit-Bulagat Mongolian pastoralists as animistic in their relations with wild animals and otherwise analogic. Descola's categories have several modes of interaction in common, making diagnosis difficult ${ }^{4}$, yet the differences between them are important: Descola argues that protection—such as pastoralists looking after animals—and transmission—such as handing things, places and substances down across generations-erode the efficacy of animism, shifting from open dialogue towards more hierarchical relations. The personhood of animals, plants and places is diluted by taking them under continual control, increasing the possibilities for incipient analogic features. A further complication is that ontologies overlap, intersect and compete. Caroline Humphreys (1995) describes the contested use of Mongolian oboo (cairns) by shamans and Buddhist priests. The shamans operate an animistic ontology in a heavily differentiated upland landscape with caves, streams, peaks, while a more analogic ontology prevails in the organisation of nomadic domestic space as animals are herded around a flat, broad landscape. These overlapping ontologies compete where landscape zones meet. People may also shift ontological modes as they engage with such different places and practitioners (cf. Harris and Robb 2012). Perhaps we can imagine similar situations in Neolithic landscapes, with locally overlapping cosmologies and ontologies. However, not all ontological categories deal with ontological diversity in the same way. For instance, analogism rigidly polices society with respect to cosmos, invoking chimeras where needed, and each event belongs in a single cosmic order which can be visualised graphically (e.g., as a cycle).

There are other problems with this approach. Graham Harvey (2006, pp. 166-68) argues that totemism and animism are 'more related than opposed', proposing that totemism is a form of animism, and animism pervades pretty much all communities in one way or another. Sahlins (2014) persuasively argues that totemism is 'the animism of segmentary collectives' while analogism is 'hierarchical animism', compared with the 'communal animism' identified by Descola as simply animism. In other words, we are left with the equation that 'non-Western ontology = animism + social organization'. Jones et al. (2011) rightly argue that it is difficult for prehistorians to distinguish between totemism and animism, and Jones has warned convincingly against slotting our evidence 'into preexisting,

3 Descola (2013, p. 279) also argues that hybrids appear in totemic fusions of human and animal collectives (though he is not referring to art here) and refers to analogic segmentation as 'not hybrid but mixed'.

4 Descola (2013, pp. 309-35) argues that all categories of ontology exhibit predation and giving as modes of interaction but these are dominant in animistic ontologies; all practice exchange but it is dominant in totemic ontologies, while protection, transmission and production are modes of action that are dominant in analogic ontologies and weak or absent in animistic and totemic ontologies (noting that totemic identity is transmitted directly from mythic beings rather than through human lineage). 
and overarching, anthropological categories' (Jones 2017, p. 176; cf. Insoll 2011). Attempts to differentiate between totemism and animism in Neolithic Britain and Ireland are, indeed, rare (e.g., Hensey 2012; Reynolds 2012; Wallis 2014). Reynolds (2012) suggests that totemism explains why deer were rarely consumed in the period, though does not present any evidence for a diagnostic association between food taboo and totemism or explain why a taboo on eating specifically deer would be widespread. While this pushes beyond a generalized sense of animacy and animism it does little beyond offering a different category of ontologies. A version of analogic ontology has arguably seeped in through contextual archaeology and post-processual work on cosmology (such as Richards 1990, 1993, 1996a, 1996b), but has not been defined as a specific ontological frame. While we might think productively about what combinations of animistic, totemic and analogic relations might have been active in different events rather than entire regions and periods, this still defers interpretation to Descola's categories ${ }^{5}$.

\section{Second Approach: What Is Not Animistic in Neolithic Britain and Ireland?}

What can be gained by reflecting on this comparative approach, even if we do not adopt it as a model? In considering this I move into the second approach: noting things which do not seem to be animistic without identifying them as specifically totemic, analogic or naturalistic. The tracing of descent and organization of the community are two examples.

Neolithic communities in Britain and Ireland built chambered tombs in which the dead were placed, sometimes along with the remains of animals, pots and tools and probably organic materials long since lost. Diversity in the results of ancient DNA analyses suggests that some of these tombs were used to bury close kin, while others were not. The subdivision of tombs into different chambers may indicate the segmentation of a community producing descent and lineal transmission-connectivity over time played out in the repeated deposition of remains within connected chambers (Fowler forthcoming). This implies the veneration of the ancestral dead, or at least human ancestry, was important in the construction of at least some of these tombs (whether reckoned in terms of biological lineages or otherwise). Descola notes that among Amazonian animistic communities 'the very idea of an ancestor seems incongruous ... the dead are excluded from human collectives and have no power over them' (Descola 2014a, p. 466). Perhaps the Neolithic dead whose tombs did not revolve around biological lineages were lodged near to their spiritual point of origin, but many Neolithic mortuary practices do not seem to chime with the kinds of animism that Descola focusses on (although other Neolithic practices may do). The variety in Neolithic mortuary practices suggest some ontological diversity in either how kinship was reckoned or what role it played in the transformation of the dead or both.

The organization of time, space and social relations became formalized in some times and places in Neolithic Britain and Ireland. By c. 3000 BC a cluster of passage tombs in the Boyne valley included some extremely large examples, two of which have passages aligned on solstice events (midwinter sunrise at Newgrange, midwinter sunset at Dowth). These have been interpreted as indicating hierarchical relations since many people would have been involved in building them, and could gather outside them, but only a few could enter the chambers at any one time (including during solstice sunrises or sunsets). The megalithic stones of these tombs are carved with arcs, latices, spirals, concentric circles and other 'abstract' motifs ${ }^{6}$ which may have been part of carefully curated knowledge systems: Hensey (2012) has suggested these may have had figurative significance in the way that motifs in Australian Aboriginal art do. This is a plausible inference, though it need not necessarily imply a totemic ontology. Hensey $(2012$, p. 172) further notes that the production of Aboriginal art forms a connection with the ancestral past; this need not necessarily be so for the Neolithic passage grave art, but if this was the case it might have been a very different kind of ancestral connection to those that could be produced by

\footnotetext{
5 I am grateful to Ollie Harris for several discussions on this latter issue.

6 It is also important to note that at least some of this art was openly figurative, depicting trees, snakes and rainbows, for instance (Robin 2012).
} 
successive deposits of human remains. Other connections with place are evident: the tombs combined materials originating in different mountain ranges, including quartz from the Wicklow Mountains c. $30 \mathrm{~km}$ to the south, and some megalithic stones forming the passages at Knowth and Newgrange seem to derive from older tombs and bear incised motifs hidden on their 'backs' which are turned into the body of the mound (e.g. Cleary and Eogan 2017, pp. 72-74). The act of assembling a monument from different originary sources could be cosmogenic. Many passage tombs in Ireland were also constructed to a common pattern. Mounds were often composed of a series of concentric layers, with large stones bounding each layer. The layers 'wrap' a central point and a linear passage to that point, marked by a series of thresholds with distinct decorative motifs: dazzling arrangements of zig-zags, lozenges or triangles. Pairs of chambers either side of this line partly mirror each other, but are also differentiated slightly by type of stone, contrasting carved or pecked motifs, size and/or contents (Robin 2010). This structure might suggest a slight hierarchy between two inseparable principles-perhaps gendered, perhaps associated with senior and junior lineages-as well as a linear journey or process of transformation (ibid.). The resulting monument could then be seen as aligning social order and cosmos in a cosmocentric way.

Similar designs are evident in the central cup-marks enclosed by concentric circles and radial lines in landscape rock art, and in the central platform enclosed by a circular ditch and bank with usually one or two linear entrances at henge monuments. This may suggest similar cosmological themes, or ontological components (potentially even cosmograms), across these later Neolithic sites which do not seem to fit best within Descola's definition of animism compared with totemism or analogism. It is also likely that these media were not produced within a singular, static ontology. As Wallis (2014) argues, the passage tomb 'art' dates from several different periods and some of it embellishes, reworks or erases older markings so it may be inappropriate to try to allocate the production of this decoration to any singular ontological effect. Wallis therefore interprets a transformation in the forms of ontology present at passage tombs during the Neolithic (Wallis 2014, pp. 302-3), although these are described as a 'complex variety of animisms through time' explored by comparing the extent of hierarchy among animistic and totemic relations (qua Pedersen 2001). Despite the nuances in exploring change this again deploys a comparative anthropological model, albeit using a different framework to Descola's: the gains and costs are therefore similar. However, the key point is that Descola's description of animism does not fit all aspects of Neolithic art and monumentality.

\section{Third Approach: Exploding Ontological Frames}

Wilkinson (2017) argues that animism does not describe a set of ontologies 'out there in the world' so much as a western attempt to grasp a range of Indigenous practices and concepts which defy simple translation: 'animism is an analytical operation that we do, not a type of religion that actual indigenous people hold to' (ibid., p. 306). For Wilkinson, animism is an 'equivocation', a heuristic stand-in for something for which there is no equivalent (ibid.). Wilkinson concludes, "Animism" does not help us understand indigenous practices; rather it illustrates how much we do not yet understand them' (ibid., p. 307). Some theories of animism have also been presented as a 'theory bomb' to explode western ontological frames and terms, perspectivism in particular (Latour 2009), but as Harris and Crellin (2018, p. 58) point out the bomb leaves 'some very specifically shaped pieces of shrapnel in its wake'. What other theory bombs might there be among other ontologies (including from communities Descola categorizes as totemic or analogic)?

Porr and Bell (2012), and Todd (2016), encourage academics to draw on the work of Indigenous theorists and recognise their descriptions of Indigenous ontologies in their own terms. This forces us to reflect on ontological diversity since many Indigenous concepts and theorists have been overlooked in discussions of ontology in Western academia (Porr and Bell 2012; Todd 2016). Todd (2016) cites Watts (2013), for instance, who presents an Indigenous theory of place-thought, developed from Anishnaabe and Haudenosaunee ontology, in which 'we (humans) are made from the land; our flesh is literally an extension 
of soil' (Watts 2013, p. 27), and in which humans engage in dialogue with the land. By contrast, relations with place, land and landscape are weakly attended to in Descola's scheme, except in his discussion of totemism.

Western academics (such as myself) have to take care not to co-opt Indigenous ontologies (Porr and Bell 2012, pp. 164-65), at the same time as acknowledging their influence (particularly via anthropology) on our recent understandings of past ontologies. Indigenous ontologies challenge the universalizing of western ontological frames (e.g., Watts 2013, p. 22), which is vitally important, but we need to be wary of using them as models for past ontologies from other parts of the world. At the same time, attending to the diversity in Indigenous theories and ontologies highlights the possibility of diversity in past ontologies. If we stick with a unitary category of animism we risk subsuming the distinctiveness of Neolithic European communities within a flattened and generic concept which does little justice to the ontologies of communities past or present. Arguably, a focus on diversity within Neolithic ontologies in Britain and Ireland is a crucial response.

\section{Fourth Approach: Ontological Difference and Diversity}

The move through the second and third approaches lead towards interpreting the specific ontological effects of Neolithic practices in processes of living, dying, and becoming. I will explore this for the Early Neolithic in southern Britain, where material worlds were arguably distinctive and different from those of any present-day communities around the world (and different from those of, say, Late Neolithic communities in the same landscapes). Inspired by Rosi Bradiotti's Deleuzian and feminist approach to identity (e.g., Braidotti 2011; cf. Deleuze [1994] 2009), Penny Bickle (2020) elegantly argues for placing difference-initself at the centre of analyses of past ways of becoming. She defines this as a process in which 'difference [is] a productive and energized space, out of which things, people, identity are created ... or 'become' ... ', and an approach in which we attend to 'the range of possibilities, not the average' (Bickle 2020, pp. 202-1) and to 'diversity within multiple ways of participating in identity in the past. (ibid., p. 204). Hers is a study of gendered differentiation in the Neolithic of central Europe. Without wishing to detract from the focus on sexual differentiation in Bickle's study, and acknowledging that I am not exploring bioarchaeological difference in the way she does, the focus on a process of becoming through multiple relationships can be applied to explore all kinds of identities. For earlier Neolithic southern Britain, for instance, we could consider becoming-kin, becoming-child, becoming-herder, becoming-potter, becoming-adult, becoming-woman, becoming-man, becoming-parent, becomingdead, becoming-ancestor, becoming-emplaced, etc. Such becomings would overlap with one another, including within one person's experience, and are always becoming-with-others, some of which are human and some of which are not, as Banfield (2018, p. 55) explores. These processes are bound up with specific affective fields and ontological effects (cf. Harris 2017; Harris and Sørensen 2010). The aim is then to differentiate ontological modes of engagement, different ways of becoming-as and becoming-with, within and between communities. In the remainder of the piece I briefly consider some ways of becoming that might have emerged in Early Neolithic activities in southern Britain as a way of exploring this approach.

The Early Neolithic is noted for the 'altering' of certain places in ways sympathetic to their local characteristics - or their personalities, as Dave Robinson (2012) has suggested. Such practices included: cracking outcrops or digging out boulders and elevating the rocks to make megalithic monuments such as portal dolmens; clearing stones, trees and undergrowth from patches of ground, and; splitting the tree trunks of massive oaks lengthways and erecting the two halves as paired posts which became the focus of later mortuary deposits and mortuary structures. David Field (2007, pp. 129-30) has suggested that the façades of some mortuary structures form horns like those of cattle, and the spineand-rib layout of withies during the construction of some long barrows and long cairns marked out a bovine body in plan. It is possible some wooden chambers, such as Fussell's Lodge, were wrapped in cattle skins, though there is no direct evidence for this (cf. Ray 
and Thomas 2003 on Early Neolithic cattle as kin). Perhaps the placement of recently deceased humans within the 'bodies' of trees, rocks and cattle highlighted the equivalence between these bodies. Human and animal bodies were generally treated quite differently even if sometimes in equivalent ways: Banfield $(2018$, p. 196) notes an 'interweaving and interdependence between human and cattle lives' alongside 'the maintenance of species distinction'. She also points out the 'equity of treatment' and 'segregated togetherness' of cattle and human remains at Fussell's Lodge (Banfield 2018, p. 82). Perhaps the human dead, or aspects of the dead, became animals or entered the bodies of animals, rocks or trees through these mortuary practices ${ }^{7}$. Other treatments show no such equivalence, such as deposits of very young cattle, sheep or goat at some Cotswold-Severn chamber tombs which may have been sacrifices (Thomas and McFadyen 2010; Banfield 2018, p. 196). Perhaps lodging bodily matter (whether human, plant or animal) at shrines and tombs demonstrated the origins of such bodies in those locales: embedding the dead in place may be particularly significant given that most of the ancestors of humans and domesticated animals living in Britain and Ireland at this time came from Continental Europe during the first centuries of the fourth millennium BC (Brace et al. 2019).

In some tombs, such as those with a central passage with rooves high enough to allow crouching entry and pairs of side cells, the human dead were accessible and their decaying remains might be revealed, lit up, tended to or negotiated with when these tombs were visited. At some-but not all—tombs, projecting or tracing descent was arguably a key concern. The dead became different kinds of kin and ancestors depending on who their remains were interred with. Different architectural features and arrangements of chambers (which could be singular, or in a short single line, or paired either side of a mound, for instance) had different effects: there is no need to imagine a single ontology or way of becoming connecting the use of all chambered tombs given that these were built in such a variety of forms (cf. Fowler forthcoming). While the vast majority of stone-built tombs formed part of one tradition or another-or one tradition and then a second, given many were modified between their initial construction and abandonmenteven those built within a similar timeframe in a given region are sufficiently diverse to suggest that creativity and specific histories were as important as the repeated replication of architectural forms. The modification of some tombs illustrates their ongoing roles in tracing histories of becoming and histories that were becoming - long, sporadic processes of becoming-lineages or other specific social collectives that built and tended them, for instance. As tombs sedimented people in place these tombs became place and history.

Causewayed enclosures were large, roughly circular ditched constructions with numerous causeways dividing up the ditches. They seem to have been built by co-operating gangs working on different ditch segments, a few centuries after the first chambered tombs in the region. They show little concern with cardinal points of the compass or regular patterns of internal division. Nor do they seem to be focused on places with earlier activity or distinctive landforms to the same extent as tombs were-Whittle et al. (2011, p. 891) refer to enclosures as 'enchant[ing] by their freshness'. At the same time, like tombs, they articulated a very limited range of architectural elements-arced ditch segments throwing up banks and sometimes post arrangements or palisades-in quite varied ways and locations. Like timber-chambered tombs, they were arenas in which bodily remains decayed-the bodies of humans, trees, animals, pots-and the successive introduction of remains fed the growing monument: mounds covered decayed wooden tombs as midden material at enclosures was buried in ditches which were repeatedly recut. A cycle of commemorative deposition of the dead, physical transformation and forgetting, and commemoration of a transformed place and community could be inferred at some of these sites (Fowler 2003), though perhaps not all. Enclosures offered new ways of becoming-dead and becomingembedded-in-place and becoming-the-past and these were pursued more extensively at some

7 To discuss a specific instance recorded by ethnographers, an aspect of a deceased person among the Orokaiva can become pigs and another aspect can become a wild animal living in the forest (Iteanu 1995). In this case becoming dead also means undoing kin relations and becoming wild. 
enclosures than others. New, large gatherings perhaps involved cosmogenic acts drawing together widespread and perhaps diverse communities-differing co-residential lineages, households or clans, perhaps. At times, violence broke out in these landscapes-we see the impact on skeletal remains in tombs and enclosure ditches (Schulting 2012). People became enemies, became allies, became affines-potentially all with the same neighbouring communities - in different modes of engagement such as raiding or feuding, burying the dead, arranging marriages, digging ditches, herding cattle, holding feasts. These events involved more-than-human communities (Harris 2014), who might have shifted into new modes of engagement when gathering at such locales compared with times of the year when they lived in smaller groups (cf. Thomas 2002; Wengrow and Graeber 2015).

People also dug linear ditches and raised banks forming cursus monuments around archaeologically 'clean' routeways. These sometimes followed the courses of rivers. Such monumental transformations could be seen as part of a deferential dialogue with nonhuman beings, such as the rivers whose courses were respected. Cursus monuments directed the flows of humans and cattle just as the rivers beside many of them directed the flow of life-giving water. A concern with the origins of waterways was also reiterated in later centuries of the Neolithic (Leary and Field 2012).

The little that remains of earlier Neolithic art includes incised chalk pendants, carved chalk or wooden figurines, phalli and balls, sometimes found at causewayed enclosures. These are rare, ephemeral things with imagery related to human bodies but seldom producing 'whole' bodies. Carved chalk phalli are about comparable in size or rather larger than equivalent human body parts - up to $30 \mathrm{~cm}$ in length, reports Teather (2008, p. 192). Figurines are small, making the body of the viewer seem large by comparison and affording human beings the ability to easily manipulate the miniature. They seldom form complete inseparable bodies-though the decay of ephemeral parts is likely-and do not offer details such as hands, feet or facial features. If there were masks, these have not survived. Animal figures and depictions of objects are extremely rare, possibly confined to a few flint mines (e.g., Teather 2015), while incised lines in abstract patterns on chalk surfaces are more common. A few centuries later, chalk plaques and 'drums' or cylinders bearing incised geometric motifs were occasionally deposited in pits, ditches and a barrow on chalklands (Teather and Kenny 2016; Jones et al. 2015). While facial features are depicted on the Folkton drums, a lack of detail and ambiguity in the bodies and faces of this art as a whole seems deliberate (cf. Thomas 2005). The process of making and decorating objects may be key to understanding their ontological significance: as Jones et al. (2015) argue, carving in chalk, working with the material, may have been the main purpose of that activity. Human bodies became-with such objects through this work. If contemporaneous human bodies were also decorated in parallel ways then decoration might acknowledge the embodied character of these things and other things, such as pottery, suggesting a sharedsense of becoming. Human bodies might have been decorated temporarily, highlighting their affinity with these decorated objects in certain events, or in more enduring ways. Yet even if human bodies were decorated like ceramic bodies, highlighting their similarity as vessels, perhaps, other differences were clear-there are no anthropomorphic vessels in this region and period, for instance. While the became together they did not become the same kinds of beings. Issues of preservation have to be considered, but it seems that entire bodies (human or otherwise) were not represented in enduring materials at the human scale either.

In common with the work of other authors cited in this article who are influenced by new materialist thinking, this approach has focused on some of a wide range of Neolithic ways of becoming without trying to categorize them in specific anthropological terms. To co-opt a phrase, this tries to take Neolithic material seriously. As such it prioritises ontological difference, diversity and specificity. We could suggest that in many cases non-human entities were what they were 'on their own terms' and had to be engaged with as such: they were present, presented at monumental locales-sometimes decorated, some composites, sometimes fragmented-and in most cases did not need representing. Of course, the exceptions might be significant, such as shaping some tombs like the bodies (or hides) 
of gigantic cattle. Earlier Neolithic bodies-human, cattle, rock, tree and others-were therefore in a process of becoming alongside one another in equivalent ways to some extent, but with different effects on one another in any interaction. Monument construction could be understood as part of dialogue with the landscape and its constituent features and materials - a dialogue that said different things in different places and over time. Making small figurines or chalk phalli, building a large tomb that would endure across generations, encountering the decayed remains of past feasts; all these interactions created and drew attention to different ontological effects for the human and other beings involved.

\section{Conclusions}

Although the new animism has helped us to think productively about the Neolithic, we do not need to evoke animism to understand Neolithic ontologies. If we do so then we must be clear about how we are using the concept and how our definition of animism relates to other ontological terms such as totemism or fetishism. Yet, such categorization constrains as much as it enables our ability to appreciate Neolithic ontologies, and pushes our accounts in specific directions. There is seldom a firm archaeological basis for choosing between alternative categories in schemes such as Descola's, even if animistic and totemic art are defined in contrast with one another-and analogism is so broad a church that it risks swamping the analysis. Neither will other comparative schemes-other modelsavoid this result, even if they provide finer gradings or combinations of categories. While trying to get a sense of 'something else' beyond the categories and terms we start with (qua Wilkinson 2017), we will never understand Neolithic ontologies in the terms of the people who lived them, and whatever approach we take (including new materialist ones) we fuse contemporary concepts with the remains of Neolithic practices in order to arrive at an accommodation of the two that is meaningful and effective in the present. This is not a pessimistic conclusion as I think this is a valuable endeavour. We do not need to refer to animism as an ontology (or any other 'type' of ontology) in order to talk about non-human persons, relational personhood, non-human beings, or the potency and efficacy of things, materials, animals or places in the Neolithic. Instead, we can focus on diverse Neolithic practices and their effects, recognising these as ontological in nature ${ }^{8}$, and situating that in a broader project to appreciate diversity within as well as across time periods and regions.

Funding: This research received no external funding.

Acknowledgments: This article started life as a keynote presentation given to the Neolithic and Early Bronze Age Research Student Symposium in Newcastle in 2015, and a talk at the Department of Archaeology at Cambridge in 2016, and I would like to thank the organisers and audiences at those events for the discussions that ensued. I would also like to thank students who participated in the module 'Themes in Prehistoric Europe: art, cosmology, bodies and persons' which I led at Newcastle between 2004 and 2017, the editors for the invitation to publish, and Chantal Conneller, Vicki Cummings, Ollie Harris and Robert Wallis for insightful comments that helped greatly improve my thinking and the article.

Conflicts of Interest: The authors declare no conflict of interest.

\section{References}

Alberti, Benjamin. 2016. Archaeologies of ontology. Annual Review of Anthropology 45: 163-79. [CrossRef]

Banfield, Emily. 2018. Tales from the Ontological Tern: An Examination of the Role and Meaning of Faunal Remains in the Neolithic Long Barrows of Wiltshire. Unpublished Ph.D. thesis, University of Leicester, Leicester, UK.

\footnotetext{
8 One reviewer raised the excellent question of how we avoid generalizing ontology so it becomes all but meaningless. There are many ways to answer this, but rather than trying to present a method for doing so (beyond stressing the importance of differentiating ontological effects as I have tried to do above), I would suggest this is part of a problem with such general concepts in the first place. The eventual redundancy of such key concepts has, for instance, been considered for culture (e.g., Strathern 1995) and the social (e.g., Webmoor and Witmore 2008). Part of what I hope the case study in this article conveys is the redundancy of drawing divisions between such conceptual fields when considering Neolithic communities. I wonder if in coming decades we will need 'ontology' any more than we need 'society' or 'culture' as prefixes to understand spheres of Neolithic action. That does not detract from its value in transforming archaeological interpretation in recent years.
} 
Bickle, Penny. 2020. Thinking gender differently: New approaches to identity difference in the Central European Neolithic. Cambridge Archaeological Journal 30: 201-18. [CrossRef]

Bird-David, Nurit. 1999. 'Animism' revisited: Personhood, environment, and relational epistemology. Current Anthropology 40: 67-92. [CrossRef]

Bird-David, Nurit. 2006. Animistic epistemology: Why do some hunter-gatherers not depict animals? Ethnos 71: 33-50. [CrossRef]

Bourdieu, Pierre. 1970. The Berber house or the world reversed. Social Science Information 9: 151-70. [CrossRef]

Brace, Selina, Yoan Diekmann, Thomas Booth, Lucy van Dorp, Zuzana Faltyskova, Nadin Rohland, Swapan Mallick, Iñigo Olalde, Matthew Ferry, Michel Megan, and et al. 2019. Ancient genomes indicate population replacement in Early Neolithic Britain. Nature Ecology \& Evolution 3: 765-77.

Bradley, Richard. 1989. Deaths and entrances: A contextual analysis of megalithic art. Current Anthropology 30: 68-75. [CrossRef]

Braidotti, Rosi. 2011. Nomadic Subjects: Embodiment and Sexual Difference in Contemporary Feminist Theory, 2nd ed. New York: Columbia University Press.

Cleary, Kerri, and George Eogan. 2017. The excavation of the great mound. In Excavations at Knowth 6: The Passage Tomb Archaeology of the Great Mound at Knowth. Edited by George Eogan and Kerri Cleary. Dublin: Royal Irish Academy, pp. 47-276.

Cochrane, Andrew, and Andrew Jones. 2012. Visualising the Neolithic: An introduction. In Visualising the Neolithic. Edited by Andrew Cochrane and Andrew Jones. Oxford: Oxbow Books, pp. 1-14.

Conneller, Chantal. 2004. Becoming deer. Corporeal transformations at Star Carr. Archaeological Dialogues 11: 37-56. [CrossRef]

Deleuze, Gilles. 2009. Difference and Repetition. Originally in French. London: Continuum. First published 1994.

Descola, Phillipe. 2013. Beyond Nature and Culture. Translated by Janet Lloyd. Chicago: University of Chicago Press.

Descola, Phillipe. 2014a. Modes of being and forms of predication. Hau 4: 271-80. [CrossRef]

Descola, Phillipe. 2014b. The difficult art of composing worlds (and of replying to objections). Hau 4: 431-43. [CrossRef]

Dronfield, Jeremy. 1995. Subjective vision and the source of Irish megalithic art. Antiquity 69: 539-49. [CrossRef]

Field, David. 2007. Earthen Long Barrows: The Earliest Monuments in the British Isles. Stroud: Tempus.

Fowler, Chris. 2003. Rates of (ex)change: Decay and growth, memory and the transformation of the dead in early Neolithic southern Britain. In Archaeologies of Remembrance. Death and Memory in Past Societies. Edited by H. Williams. New York: Kluwer Academic, New York: Plenum Press, pp. 45-63.

Fowler, Chris. 2004. The Archaeology of Personhood: An Anthropological Approach. London: Routledge.

Fowler, Chris. 2016. Relational personhood revisited. Cambridge Archaeological Journal 26: 397-412. [CrossRef]

Fowler, Chris. forthcoming. Social arrangements: Kinship, descent and affinity in the mortuary architecture of Early Neolithic Britain and Ireland. Archaeological Dialogues. In press.

Gillings, Mark, and Joshua Pollard. 2016. Making megaliths: Shifting and unstable stones in the Neolithic of the Avebury landscape. Cambridge Archaeological Journal 26: 537-59. [CrossRef]

Harris, Oliver. 2014. (Re)assembling communities. Journal of Archaeological Method and Theory 21: 76-97.

Harris, Oliver. 2017. From emotional geographies to assemblages of affect: Emotion in archaeology in the light of the ontological turn. Cologne Contributions to Archaeology and Cultural Studies 2: 175-94.

Harris, Oliver, and Rachel Crellin. 2018. Assembling new ontologies from old materials: Towards multiplicity. In Rethinking Relations and Animism: Personhood and Materiality. Edited by Miguel Astor-Aguilera and Graham Harvey. London: Routledge, pp. 55-74.

Harris, Oliver, and John Robb. 2012. Multiple ontologies and the problem of the body in history. American Anthropologist 114: 668-79. [CrossRef]

Harris, Oliver, and Tim Flohr Sørensen. 2010. Rethinking emotion and material culture. Archaeological Dialogues 17: $145-63$.

Harvey, Graham. 2006. Animism: Respecting the Living World. London: Hurst and Company.

Hensey, Robert. 2012. Assuming the jigsaw had only one piece: Abstraction, figuration and the interpretation of Irish passage tomb art. In Visualising the Neolithic. Edited by Andrew Cochrane and Andrew Jones. Oxford: Oxbow, pp. 161-78.

Humphreys, Caroline. 1995. 'Shamanic' and 'Chiefly' landscapes. In The Anthropology of Landscape: Perspectives on Place and Space. Edited by Eric Hirsch and Michael O'Hanlon. Oxford: Clarendon.

Ingold, Tim. 2000. Totemism, Animism and the Depiction of Animals. In The Perception of the Environment: Essays in Livelihood, Dwelling and Skill. Edited by Tim Ingold. London: Routledge, pp. 111-31.

Insoll, Tim. 2011. Animism and totemism. In The Oxford Handbook of Ritual and Religion in Archaeology. Edited by Tim Insoll. Oxford: Oxford University Press.

Iteanu, Andre. 1995. Rituals and ancestors. In Cosmos and Society in Oceania. Edited by Daniel de Coppet and Andre Iteanu. Oxford: Berg, pp. 135-63.

Johnston, Robert. 2020. Bronze Age worlds: A Social Prehistory of Britain and Ireland. London: Routledge.

Jones, Andrew. 2004. By way of illustration: Art, memory and materiality in the Irish Sea and beyond. In The Neolithic of the Irish Sea: Materiality and Traditions of Practice. Edited by Vicki Cummings and Chris Fowler. Oxford: Oxbow Books, pp. 202-13.

Jones, Andrew. 2006. Animated images: Images, agency and landscape in Kilmartin, Argyll, Scotland. Journal of Material Culture 11: 211-25. [CrossRef]

Jones, Andrew. 2012. Prehistoric Materialities: Becoming Material in Prehistoric Britain and Ireland. Oxford: Oxford University Press.

Jones, Andrew. 2017. Rock art and ontology. Annual Review of Anthropology 46: 167-81. [CrossRef] 
Jones, Andrew. 2020. An archaeology of affect: Art, ontology and the carved stone balls of Neolithic Britain. Journal of Archaeological Method and Theory. [CrossRef]

Jones, Andrew, and Marta Diaz-Guardamino. 2019. Making a Mark: Image and Process in Neolithic Britain and Ireland. Oxford: Oxbow.

Jones, Andrew, Blaze O'Connor, Hugo Lamdin-Whymark, Richard Tipping, and Aaron Watson. 2011. An Animate Landscape: Rock Art and the Prehistory of Kilmartin, Argyll, Scotland. Oxford: Windgather Press.

Jones, Andrew, Andrew Cochrane, Chris Carter, Ian Dawson, Marta Diaz-Guardamino, Eleni Kotoula, and Louisa Minkin. 2015. Digital imaging and prehistoric imagery: A new analysis of the Folkton Drums. Antiquity 89: 1083-95. [CrossRef]

Latour, Bruno. 2009. Perspectivism: 'type' or 'bomb'? Anthropology Today 25: 1-2. [CrossRef]

Leary, Jim, and David Field. 2012. Journeys and juxtapositions: Marden henge and the view from the Vale. In Image, Memory and Monumentality: Archaeological Engagements with the Material World. Edited by Andrew Jones, Joshua Pollard, Mike Allen and Julie Gardiner. Oxford: Oxbow.

Lewis-Williams, David, and Thomas Dowson. 1993. On vision and power in the Neolithic: Evidence from the decorated monuments. Current Anthropology 34: 55-65. [CrossRef]

Lewis-Williams, David, and David Pearce. 2005. Inside the Neolithic mind: Consciousness, Cosmos and the Realm of Gods. London: Thames and Hudson.

McFadyen, Lesley. 2006. Building technologies, quick and slow architectures and early Neolithic long barrow sites in southern Britain. Archaeological Review from Cambridge 21: 117-34.

Moore, Henrietta. 1986. Space, Text and Gender: An Anthropological Study of the Marakwet of Kenya. Cambridge: Cambridge University Press.

Morphy, Howard. 2007. Becoming Art: Exploring Cross-Cultural Categories. Oxford: Berg/Bloomsbury.

Oxenham, Marc, Tom Knight, and Michael Westaway. 2008. Identification of Australian Aboriginal mortuary remains. In Forensic Approaches to Death, Disaster and Abuse. Edited by Marc Oxenham. Bowen Hills: Australian Academic Press, pp. 37-54.

Pedersen, Axel. 2001. Totemism, animism and North Asian indigenous ontologies. Journal of the Royal Anthropological Institute 7: 411-27. [CrossRef]

Pollard, Joshua. 2012. Living with sacred spaces: The henge monuments of Wessex. In Enclosing the Neolithic: Recent studies in Britain and Europe. Edited by Alex Gibson. British Archaeological Reports, International Series; No. 2440; Oxford: Archaeopress, pp. 93-107.

Pollard, Joshua. 2013. From Ahu to Avebury: Monumentality, the social, and relational ontologies. In Archaeology after Interpretation: Returning Materials to Archaeological Theory. Edited by Benjamin Alberti, Andrew Jones and Joshua Pollard. Walnut Creek: Left Coast Press, pp. 177-96.

Porr, Martin, and Hannah Rachel Bell. 2012. 'Rock-art', 'animism' and two-way thinking: Towards a complementary epistemology in the understanding of material culture and 'rock-art' of hunting and gathering people. Journal of Archaeological Method and Theory 19: 161-205. [CrossRef]

Ray, Keith, and Julian Thomas. 2003. In the kinship of cows: The social centrality of cattle in the earlier Neolithic of Southern Britain. In Food, Culture and Identity in the Neolithic and Early Bronze Age. Edited by Mike Parker Pearson. BAR International Series 1117; Oxford: BAR International, pp. 45-51.

Reynolds, Ffion. 2012. Totemism and food taboos in the early Neolithic: A feast of roe deer at the Coneybury 'Anomaly', Wiltshire, southern Britain. In Regional Perspectives on Neolithic pit Deposition: Beyond the Mundane. Edited by Hugo Anderson-Whymark and Julian Thomas. Seminar Papers 12. Oxford: Neolithic Studies Group, pp. 171-86.

Richards, Colin. 1990. Monuments as landscape: Creating the centre of the world in late Neolithic Orkney. World Archaeology 28: 190-208. [CrossRef]

Richards, Colin. 1993. 'Monumental choreography: Architecture and spatial representation in Late Neolithic Orkney'. In Interpretative Archaeology. Edited by Chris Tilley. Oxford: Berg, pp. 143-78.

Richards, Colin. 1996a. Henges and water: Towards an elemental understanding of monumentality and landscape in late Neolithic Britain. Journal of Material Culture 1: 313-36. [CrossRef]

Richards, Colin. 1996b. Life is not that simple: Architecture and cosmology in the Balinese house. In Neolithic Houses in Northwest Europe and Beyond. Edited by Tim Darvill and Julian Thomas. Oxford: Oxbow, pp. 173-84.

Richards, Colin. 2013. Interpreting stone circles. In Building the Great Stone Circles of the North. Edited by Colin Richards. Oxford: Windgather, pp. 2-28.

Richards, Colin, and Joanna Wright. 2013. Monuments in the making. In Building the Great Stone Circles of the North. Edited by Colin Richards. Oxford: Windgather, pp. 31-61.

Robb, John. 2017. 'Art' in Archaeology and Anthropology: An Overview of the Concept. Cambridge Archaeological Journal 27: 587-97. [CrossRef]

Robin, Guillaume. 2010. Spatial Structures and Symbolic Systems in Irish and British Passage Tombs: The Organization of Architectural Elements, Parietal Carved Signs and Funerary Deposits. Cambridge Archaeological Journal 20: 373-418. [CrossRef]

Robin, Guillaume. 2012. The figurative part of an abstract Neolithic iconography: Hypotheses and directions of research in Irish and British passage tomb art. In Visualising the Neolithic. Edited by Andrerw Cochrane and Andrew Jones. Oxford: Oxbow Books, pp. 140-60. 
Robinson, David. 2012. Discussion: Personality and Neolithic visual media. In Visualising the Neolithic. Edited by Andrew Cochrane and Andrew Jones. Oxford: Oxbow, pp. 291-300.

Sahlins, Marshall. 2014. On the ontological scheme of Beyond nature and Culture. Hau 4: 281-90. [CrossRef]

Schulting, Rick. 2012. Skeletal evidence for interpersonal violence: Beyond mortuary monuments in southern Britain. In Sticks, stones and Broken Bones: Neolithic Violence in a European Perspective. Edited by Rick Schulting and Linda Fibiger. Oxford: Oxford University Press, pp. 223-49.

Simay, Philippe, and Philippe Descola. 2012. What Images Show: An Interview with Philippe Descola. Available online: http:/ / www.laviedesidees.fr/IMG/pdf/20120405_descola-images.pdf (accessed on 24 March 2021).

Solomon, Anne. 2014. The death of trance: Recent perspectives on San ethnographies and rock arts. Antiquity 88: 1208-13. [CrossRef]

Strathern, Marilyn. 1995. The nice thing about culture is that everyone has it. In Shifting Contexts: Transformations in Anthropological Knowledge. Edited by Marilyn Strathern. London: Routledge, pp. 153-76.

Teather, Anne. 2008. Mining and Materiality in the British Neolithic. Unpublished Ph.D. dissertation, University of Sheffield, Sheffield, UK.

Teather, Anne. 2015. The first British Neolithic Representational Art? The Chalk Engravings at Cissbury Flint Mine. Antiquity. 89. Project Gallery. Available online: https:/ / antiquity.ac.uk/projgall/teather347 (accessed on 30 March 2021).

Teather, Anne, and James Kenny. 2016. New insights into the Neolithic chalk drums from Folkton (North Yorkshire) and Lavant (West Sussex). Past 83: 5-6.

Thomas, Julian. 2002. Taking power seriously. In The Dynamics of Power. Edited by M. O'Donovan. Carbondale: Southern Illinois University Press, pp. 35-50.

Thomas, Julian. 2005. Ambiguous symbols: Why there were no figurines in Neolithic Britain. Documenta Praehistorica XXXII: 167-75.

Thomas, Richard, and Lesley McFadyen. 2010. Animals and Cotswold-Severn long-barrows: A re-examination. Proceedings of the Prehistoric Society 76: 95-113. [CrossRef]

Todd, Zoe. 2016. An Indigenous feminist's take on the ontological turn: 'Ontology' is just another word for colonialism. Journal of historical sociology 29: 4-22. [CrossRef]

Viveiros de Castro, Eduardo. 1998. Cosmological deixis and Amerindian perspectivism: A view from Amazonia. Journal of the Royal Anthropological Institute 4: 469-88. [CrossRef]

Wallis, Robert. 2009. Re-enchanting rock art landscapes: Animic ontologies, non-human agency and rhizomic personhood. Time and Mind: The Journal of Archaeology, Consciousness and Culture 2: 47-70. [CrossRef]

Wallis, Robert. 2014. Animism, ancestors and adjusted styles of communication: Hidden art in Irish passage tombs. In Archaeological Imaginations of Religion. Edited by T. Meier and P. Tillessen. Budapest: Archaeolingua, pp. 283-314.

Watts, Vanessa. 2013. Indigenous place-thought and agency amongst humans and non-humans (First Woman and Sky Woman go on a European tour!). DIES: Decolonization, Indigeneity, Education and Society 2: 20-34.

Webmoor, Timothy, and Chris Witmore. 2008. Things are us! A commentary on human/things relations under the banner of a 'social' archaeology. Norwegian Archaeology Review 41: 53-70. [CrossRef]

Wengrow, David. 2014. The Origins of Monsters: Image and Cognition in the First Age of Mechanical Reproduction. New Jersey: Princeton University Press.

Wengrow, David, and David Graeber. 2015. Farewell to the 'childhood of man': Ritual, seasonality, and the origins of inequality. Journal of the Royal Anthropological Association 21: 597-619. [CrossRef]

Whittle, Alasdair, Bayliss Alex, and Healy Frances. 2011. Gathering time: The social dynamics of change. In Gathering Time: Dating the Early Neolithic Enclosures of Southern Britain and Ireland. Edited by Alasdair Whittle, Frances Healy and Alex Bayliss. Oxford: Oxbow Books.

Wilkinson, Darryl. 2017. Is there such a thing as animism? Journal of the American Academy of Religion 85: 289-311. [CrossRef] 